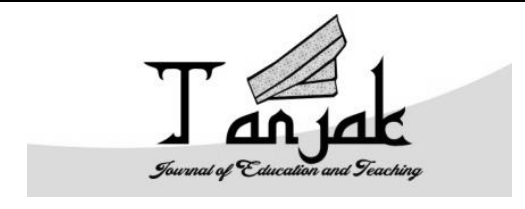

\author{
Tanjak: Journal of Education and Teaching \\ ISSN 2716-4098 (P) 2720-8966 (O) \\ Volume 1 Nomor 2, 2020
}

\title{
ANALISIS KEPUASAN PENGGUNAAN APLIKASI ZOOM DALAM MENGIKUTI WEBINAR SELAMA PANDEMI COVID-19 MENGGUNAKAN WEBQUAL 4.0 (STUDI KASUS: DOSEN STAIN SULTAN ABDURRAHMAN KEPRI)
}

\author{
Muslena Layla, M.Si \\ STAIN Sultan Abdurrahman Kepulauan Riau, muslenalayladlmt@gmail.com
}

DOI: https://doi.org/10.35961/tanjak.v1i2.142

\begin{abstract}
Abstrak
Pandemi Koronavirus 2019-2020 merupakan peristiwa penyebaran penyakit koronavirus 2019 (coronavirus disease 2019) yang mengakibatkan berbagai dampak di Indonesia. Salah satunya adalah terkendalanya kegiatan seperti seminar dan workshop termasuk di STAIN Sultan Abdurrahman Kepulauan Riau. Namun kegiatan-kegiatan seminar dan workshop tetap dapat dilaksanakan secara virtual menggunakan Zoom Meeting. Untuk mengetahui tingkat kepuasan pengguna Zoom Meeting di STAIN Sultan Abdurrahman dilakukan penelitian berupa pengisian kuisioner berdasarkan metode webqual. Metode webqual merupakan salah satu Teknik pengukuran kualitas website. Pengukuran dilakukan berdasarkan kriteria usability, information quality, dan service interaction. Dari hasil analisis diperoleh kesimpulan bahwa di lingkungan STAIN Sultan Abdurrahman Kepulauan Riau ketiga variabel tersebut memberikan pengaruh secara positif terhadap kepuasan penggunaan Zoom Meeting. Variabel yang memberikan pengaruh dominan adalah variabel service interaction.
\end{abstract}

Kata kunci: Zoom meeting; usability; informatin quality; service interaction; corona virus.

Tanjak: Jounal of Education and Teaching, Vol. 1, No. 2, 2020 


\section{Abstract}

The Pandemi Of Coronaviruses 2019-2020 is the event of the spread of corona virus 2019 (coronavirus disease 2019) which had various impacts in Indonesia. One of them is the constrained activities such as seminars and workshop in STAIN Sultan Abdurrahman Kepulauan Riau. However, seminar and workshop activities can still be carried out virtually using Zoom Meeting. To find out the level of satisfaction of Zoom Meeting users at STAIN Sultan Abdurrahman Kepulauan Riau researcher did it in the form of filling out a questionaires based on the webqual method. Webqual method is one of the techniques for measuring website quality. Measuring were made based on usability, information quality, and service interaction criteria. From the analysist, it was concluded that in the STAIN Sultan Abdurrahman Kepulauan Riau, the three of variable have a positive effect on satisfaction using Zoom Meeting. The influence of the dominant variable is the service interaction variable.

Keywords: Zoom meeting; usability; informatin quality; service interaction; corona virus

\section{Pendahuluan}

Pandemi Koronavirus 2019-2020 merupakan peristiwa penyebaran penyakit koronavirus 2019 (coronavirus disease 2019) dan kemudian lebih dikenal sebagai Pandemi Covid-19. Penyakit ini disebabkan oleh koronavirus jenis baru yaitu SARS-CoV-2 yang pertama kali dideteksi di kota Wuhan, Provinsi Hubei, Tiongkok pada Desember 2019. Penyakit ini dapat menyebabkan gangguan sistem pernapasan, mulai dari gejala yang ringan seperti flu, hingga infeksi paru-paru seperti pneumonia. Penyakit ini kemudian ditetapkan sebagai pandemi oleh Organisasi Kesehatan Dunia (WHO) pada 11 Maret 2020. Hingga April 2020 lebih dari dua juta kasus Covid-19 telah dilaporkan di lebih dari 210 negara dan wilayah di dunia.

Salah satu negara yang terdampak pandemi Covid-19 ini adalah Indonesia. Di Indonesia sendiri kasus Covid-19 sudah menyebar hampir di seluruh wilayah. Berdasarkan data yang terdapat di situs resmi Gugus Tugas Percepatan Penanganan Covid-19 Nasional pada tanggal 5 Juli 2020 jumlah kasus positif di Indonesia telah mecapai 63.749 kasus.

Mengingat penyebaran Covid-19 yang begitu cepat, pemerintah Indonesia melakukan beberapa upaya pencegahan penyebaran virus. Beberapa upaya yang dilakukan pemerintah Indonesia adalah dengan memberlakukan pembatasan wilayah (lockdown) dan Pembatasan Sosial Beerskala Besar (PSBB). Pembatasan tersebut meliputi peliburan sekolah dan tempat kerja, pembatasan kegiatan keagamaan, pembatasan kegiatan di tempat dan fasilitas umum, pembatasan kegiatan sosial budaya, pembatasan moda transportasi, dan pembatasan kegiatan lain khususnya terkait aspek pertahanan dan keamanan.

Pembatasan wilayah dan aktivitas terutama di instansi-instansi pendidikan mengakibatkan kegiatan-kegiatan seperti seminar dan workshop tidak dapat dilakukan seperti biasanya. Agar kegiatan tetap dapat berjalan maka dicarilah alternatif lain dalam pelaksaannya. Media video conference dipilih sebagai salah satu alternatif yang sangat membantu. Dengan media video conference instansi yang akan melaksanakan kegiatan seminar ataupun workshop tetap dapat melaksanakannya secara virtual tanpa harus mengumpulkan banyak orang. Peserta seminar juga lebih mudah mengikuti kegiatan secara virtual. Media yang sering digunakan untuk mengadakan seminar dan workshop tersebut adalah Zoom Meeting.

Zoom adalah aplikasi buatan seorang miliader bernama Eric Yuan, yang dirilis pada Januari 2013. Selain berupa aplikasi, Zoom juga dapat diakses melalui website, baik untuk OS Mac, Window, 
Linux, iOs, dan Android. Aplikasi Zoom merupakan aplikasi yang banyak digunakan di Indonesia. Aplikasi ini memiliki jenis akun Basic yang memiliki keuntungan yaitu, dapat melakukan meeting hingga 100 partisipan, gratis 40 menit video conference untuk rapat kelompok dan dapat diulang, kualitas dan suara HD, screen sharing, akses ke virtual background, menjadwalkan dan merekam meeting dan membagi partisipan menjadi beberapa "room" dengan fitur "Breakout Rooms". Namun jika membutuhkan "room" untuk lebih dari 40 menit atau lebih dari 100 partisipan, maka dapat menggunakan akun Pro, Business, atau Enterprise dengan harga sekitar 200 ribuan per bulan.

Dosen di STAIN Sultan Abdurrahman Kepulauan Riau telah memanfaatkan Zoom Meeting ini untuk mengikuti kegiatan-kegiatan seminar atau yang dikenal dengan webinar, baik yang diadakan oleh STAIN Sultan Abdurrahman Kepulauan Riau sendiri atau yang diadakan oleh instansi lain. Oleh karena itu, penulis ingin mengetahui bagaimana kepuasan dosen STAIN Sultan Abdurrahman Kepulauan Riau terhadap penggunaan Zoom Meeting tersebut. Penulis melakukan pengukuran tersebut dengan menggunakan metode Webqual.

Metode Webqual merupakan salah satu teknik pengukuran untuk menentukan kualitas website. Metode Webqual menggunakan pendekatan perception dan importance dari pengguna. Persepsi pengguna tentang suatu sistem informasi yang baik adalah sistem yang dimana pengguna merasa puas dengan kualitas website. Kualitas ini termuat dalam tiga dimensi dari Webqual versi 4.0. Webqual 4.0 mengukur mutu website berdasarkan persepsi dari pengguna website. Maka pengukurannya menggunakan instrument penelitian atau kuisioner. (S. Barnes and R. Vidgen, 1998)

\section{Metode Penelitian}

Penelitian yang akan dilakukan adalah penelitian deskriptif kuantitatif. Variable-variabel yang akan digunakan pada penelitian ini berdasarkan pada metode Webqual versi 4.0 yang dilakukan oleh Barnes dan Vidgen sebelumnya. Variable tersebut terdiri dari usability, information quality, service interaction yang terdiri dari 22 total indikator. Indikator-indikator tersebut dibedakan menjadi dua jenis, yaitu kualitas yang dirasakan pengguna saat ini (performace) dan kualitas yang diharapkan dan dianggap penting untuk dikembangkan (importance).

Tabel 1.

Instrument Webqual 4.0

\begin{tabular}{|c|c|c|}
\hline Kategori & Kuisioner WebQual 4.0 & $\begin{array}{c}\text { Penamaan } \\
\text { Variabel }\end{array}$ \\
\hline \multirow[t]{8}{*}{ Usability } & 1. I find the site easy to learn to operate & U1 \\
\hline & 2. My interaction with the site is clear and understandable & $\mathrm{U} 2$ \\
\hline & 3. I find the site easy to navigate & U3 \\
\hline & 4. I find the site easy to use & U4 \\
\hline & 5. The site has an attractive appearance & U5 \\
\hline & 6. The design is appropriate to the type of site & U6 \\
\hline & 7. The site conveys a sense of competency & U7 \\
\hline & 8. The site creates a positive experience for me & U8 \\
\hline Information & 9. Provides accurate information & $\mathrm{I} 1$ \\
\hline
\end{tabular}




\begin{tabular}{|l|l|c|}
\hline Quality & 10. Provides believable information & $\mathrm{I} 2$ \\
\cline { 2 - 3 } & 11. Provides timely information & $\mathrm{I} 3$ \\
\cline { 2 - 3 } & 12. Provides relevant information & $\mathrm{I}$ \\
\cline { 2 - 3 } & 13. Provides easy to understand information & $\mathrm{I} 5$ \\
\cline { 2 - 3 } & 14. Provides information at the right level of detail & $\mathrm{I} 6$ \\
\cline { 2 - 3 } & 15. Presents the information in an appropriate format & $\mathrm{I} 7$ \\
\hline Service Interaction & 16. Has a good reputation & $\mathrm{S} 1$ \\
\cline { 2 - 3 } & 17. It feels safe to complete transactions & $\mathrm{S} 2$ \\
\cline { 2 - 3 } & 18. My personal information feels secure & $\mathrm{S} 3$ \\
\cline { 2 - 3 } & 19. Creates a sense of personalization & $\mathrm{S} 4$ \\
\cline { 2 - 3 } & 20. Conveys a sense of community & $\mathrm{S} 5$ \\
\cline { 2 - 3 } & 21. Makes it easy to cummunicate with the organization & $\mathrm{S} 6$ \\
\cline { 2 - 3 } & 22. I feel confidet that goods/services will be delivered as \\
& promised & $\mathrm{S} 7$ \\
\hline
\end{tabular}

Pertanyaan-pertanyaan diatas akan disebar dalam bentuk kuisioner. Kuisioner akan disebar kepada dosen STAIN Sultan Abdurrahman Kepulauan Riau yang terdiri dari 23 orang Dosen Tetap Non PNS dan 53 Dosen PNS.

Kuisioner yang digunakan berdasarkan skala Likert. Skala Likert merupakan skala penelitian yang digunakan untuk mengukur sikap dan pendapat. Responden diminta untuk melengkapi kuisioner yang mengharuskan mereka untuk menunjukkan tingkat persetujuan terhadap pertanyaan-pertannya tersebut. Tingkat persetujuan yang dimaksud dalam skala Likert ini terdiri dari 5 pilihan skala yaitu, (1) Sangat Setuju (SS), (2) Setuju (S), (3) Netral (N), (4) Tidak Setuju (TS), (5) Sangat Tidak Setuju (STS).

Jawaban dari responden akan diberi bobot penilaian agar dapat dihitung dan dianalisis secara kuantitatif. Pembobotan tersebut yaitu, (1) Sangat Setuju diberi bobot 5, (2) Setuju diberi bobot 4, (3) Netral diberi bobot 3, (4) Tidak Setuju diberi bobot 2, (5) Sangat Tidak Setuju diberi bobot 1.

\section{Hasil dan Pembahasan}

Data yang telah diperoleh kemudian dianalisis untuk kemudian dijadikan dasar pengambilan keputusan. Tujuan dilakukannya analisis data adalah untuk menginterpretasikan dan menarik kesimpulan dari sejumlah data yang terkumpul. Data tersebut akan diolah menggunakan aplikasi statistika yaitu SPSS.

\section{Uji Validitas}

Setiap instrument penelitian perlu dilakukan uji validitas untuk mengetahui sejauh mana ketepatan dan kecermatan instrument tersebut dalam melakukan fungsi ukurnya. Dengan jumlah responden sebanyak 76 orang $(\mathrm{N}=76)$ dan taraf signifikansi 0.05 maka nilai Pearson Correlation $(r)$ pada table adalah 0.2318. Item kuisioner dikatakan valid jika nilai $r$ hitung lebih besar dari $r$ tabel. Dari hasil analisis menggunakan SPSS, pada setiap item kuisioner diperoleh nilai $r$ hitung setiap item lebih besar dari 0.2318 ( $r$ table). Sehingga semua item pada kuisioner tersebut sudah valid.

\section{Uji Reliabilitas}


Uji reliabilitas dilakukan untuk menguji konsistensi alat ukur. Tujuannya adalah untuk mengetahui apakah instrumen kuisioner akan menghasilkan hasil yang tetap konsisten jika pengukuran diulang. Suatu instrumen dikatakan reliabel jika pertanyaan yang sama diulang kepada seseorang, maka jawaban yang dihasilkan tetap sama dari waktu ke waktu. Pada penelitian ini uji yang digunakan adalah metode Cronbach Alpha. Jika nilai alpha yang diperoleh lebih kecil dari 0.50 maka instrumen dikatakan memiliki reliabilitas rendah. Jika alpha yang diperoleh pada rentang $0.50-0.70$ maka instrumen dikatakan memiliki reabilitas moderat. Jika alpha lebih dari 0.70 maka instrument dikatakan reliabilitas mencukupi. Dan jika alpha lebih dari 0.80 maka instrumen memiliki reliabilitas kuat.

Dari hasi analisis menggunakan SPSS, terlihat pada table nilai Cronbach's Alpha yang diperoleh adalah 0.977 yang artinya instrument tersebut memiliki reabilitas kuat. Sehingga dapat dikatakan bahwa kuisioner ini tetap konsisten jika dilakukan pengukuran kembali.

\section{Uji Asumsi Klasik}

\section{a. Multikolinearitas}

Syarat regresi dikatakan baik adalah jika tidak terdapat multikolinearitas. Untuk mengetahuinya dari hasil pengolahan data menggunakan SPSS dapat dilihat nilai tolerance dan VIF. Jika nilai tolerance lebih dari 0,1 dan VIF kurang dari 10 maka tidak terjadi multikolinearitas. Pada data diatas, setelah dilakukan pengolahan menggunakan SPSS diperoleh hasil sebagai berikut

Tabel 2.

Hasil Uji Multikolinearitas

\begin{tabular}{|l|l|l|l|}
\hline No & Variabel & Nilai tolerance & Nilai VIF \\
\hline 1 & Variable Usability & 0.196 & 5.105 \\
\hline 2 & Variable Information Quality & 0.149 & 6.711 \\
\hline 3 & Service Interaction & 0.223 & 4.493 \\
\hline
\end{tabular}

Dari tabel diatas dapat dilihat bahwa nilai tolerance lebih dari 0.1 dan nilai VIF kurang dari 10. Maka tidak terjadi multikolinearitas pada data tersebut.

\section{b. Heteroskedastisitas}

Gambar 1.

Hasil Uji Heteroskedastisitas dengan Scatterplot 


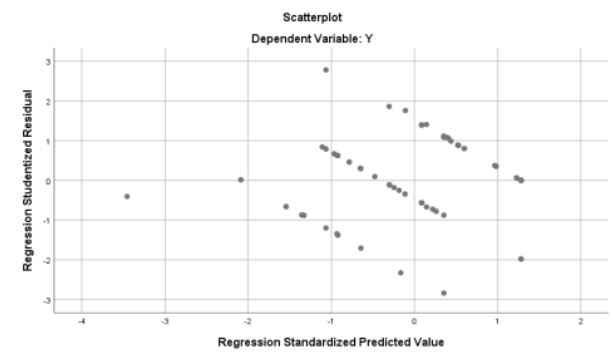

Pengujian heteroskedastisitas pada scatterplot diatas dapat dilihat bahwa titik-titik tidak membentuk pola tertentu. Titik-titik tersebut menyebar di atas dan dibawah angka nol pada sumbu $Y$. Dengan demikian pada data diatas tidak terjadi heteroskedastisitas.

\section{c. Autokorelasi}

Pada hasil pengolahan data menggunakan SPSS diperoleh nilai Durbin Watson sebesar 1.871, dan nilai Durbin Watson pada tabel dengan taraf signifikansi 5\% diperoleh nilai $\mathrm{dL}=1.5190$; $\mathrm{dU}=$ 1.7399; 4-dL $=2.481 ; 4-\mathrm{dU}=2.2601$. Syarat tidak terjadi autokorelasi adalah dipenuhinya syarat $\mathrm{dL}<\mathrm{DW}<4-\mathrm{dU}$. Dari hasil diatas diperoleh $1.5190<1.871<2.2601$. Dengan demikian pada data tersebut tidak terjadi autokorelasi.

\section{d. Normalitas Data}

Model regresi harus memenuhi asumsi normalitas. Data dikatakan normal jika menyebar di sekitar garis diagonal dan mengikuti arah diagonal. Sedangkan jika data menyebar jauh dari garis diagonal maka asumsi normalitas tidak dipenuhi.

Gambar 2.

Hasil Uji Normalitas P-P Plot Regression Standardizet Residual

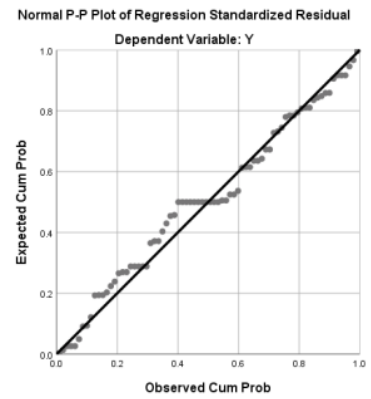

\section{e. Model Regresi}

Model regresi untuk data diatas adalah sebagai berikut

$$
\mathrm{Y}=\mathrm{a}+\mathrm{b}_{1} \mathrm{X}_{1}+\mathrm{b}_{2} \mathrm{X}_{2}+\mathrm{b}_{3} \mathrm{X}_{3}
$$


Hasil pengolahan data menggunakan SPSS diperoleh nilai-nilai untuk koefisien regresi sebagai berikut:

Table 3.

Hasil Perhitungan Koefisien Regresi

\begin{tabular}{|c|c|c|c|c|c|c|}
\hline \multicolumn{7}{|c|}{ Coefficients $^{a}$} \\
\hline \multirow[b]{2}{*}{ Model } & & \multicolumn{2}{|c|}{ Unstandardized Coefficients } & \multirow{2}{*}{$\begin{array}{l}\text { Standardized } \\
\text { Coefficients } \\
\text { Beta }\end{array}$} & \multirow[b]{2}{*}{$t$} & \multirow[b]{2}{*}{ Sig. } \\
\hline & & B & Std. Error & & & \\
\hline \multirow[t]{4}{*}{1} & (Constant) & 1.439 & .343 & & 4.192 & .000 \\
\hline & Usability & .086 & .184 & .080 & .464 & .644 \\
\hline & InformationQuality & 187 & .181 & .204 & 1.032 & .305 \\
\hline & Servicelnteraction & .439 & .140 & .507 & 3.139 & .002 \\
\hline
\end{tabular}

Dari tabel diatas maka diperoleh persamaan model regresinya sebagai berikut

$$
\mathrm{Y}=1.439+0.086 \mathrm{X}_{1}+0.187 \mathrm{X}_{2}+0.439 \mathrm{X}_{3}
$$

Persamaan regresi diatas menunjukkan bahwa koefisien semua variabel bebas bernilai positif. Dan terlihat bahwa variabel service interaction merupakan variable yang memberi pengaruh dominan terhadap kepuasan pengguna Zoom Meeting dengan nilai 0.493 .

Table 4.

Hasil Perhitungan Koefisien Korelasi

\begin{tabular}{|c|c|c|c|c|}
\hline \multicolumn{5}{|c|}{ Model Summary } \\
\hline Model & $\mathrm{R}$ & R Square & $\begin{array}{c}\text { Adjusted R } \\
\text { Square }\end{array}$ & $\begin{array}{l}\text { Std. Error of } \\
\text { the Estimate }\end{array}$ \\
\hline 1 & $.763^{\mathrm{a}}$ & .582 & .565 & .515 \\
\hline
\end{tabular}

Tabel diatas menunjukkan bahwa besarnya koefisien korelasi sebesar 0.763. Nilai yang cukup besar tersebut menyatakan bahwa variabel bebas (Usability, Information Quality dan Service Interaction) mempunyai hubungan yang kuat dengan variabel Kepuasan Pengguna. Nilai koefisien determinasi ( $R$ square) sebesar 0.582, yang berarti bahwa $58.2 \%$ variabel bebas mampu menjelaskan variabel terikatnya.

\section{Uji T dan Uji F}

Tabel 5.

Hasil Uji T dan Uji F

\begin{tabular}{|l|l|c|c|c|c|}
\hline No & Variabel & $\begin{array}{c}\text { Nilai T } \\
\text { Hitung }\end{array}$ & $\begin{array}{c}\text { Nilai } \\
\text { T } \\
\text { Tabel }\end{array}$ & $\begin{array}{c}\text { Nilai F } \\
\text { Hitung }\end{array}$ & $\begin{array}{c}\text { Nilai } \\
\text { F } \\
\text { Tabel }\end{array}$ \\
\hline 1 & Variabel & 0.464 & 0.6778 & 33.409 & 3.12 \\
\hline
\end{tabular}




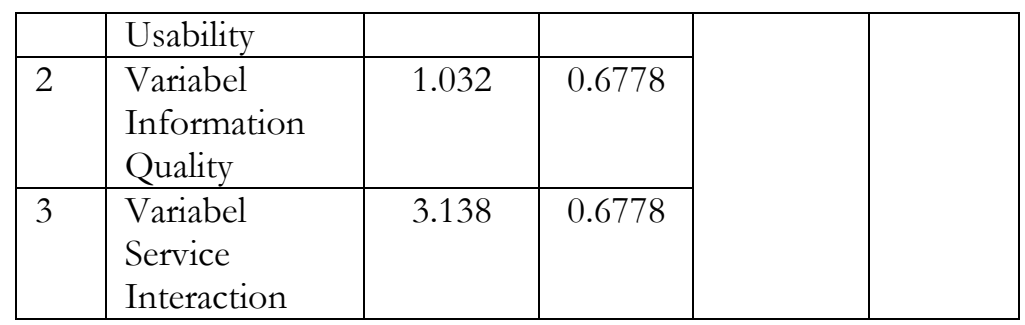

Dari tabel diatas diperoleh bahwa nilai $t$ hitung variabel Usability (0.464) lebih kecil dari nilai $t$ tabel (0.6778). Artinya variabel Usability tidak berpengaruh secara signifikan terhadap kepuasan pengguna. Untuk variabel Information Quality nilai $t$ hitung (1.032) lebih besar dari $t$ table. Sehingga dapat dikatakan bahwa variabel Information Quality berpengaruh secara signifikan terhadap Kepuasan Pengguna. Selanjutnya, untuk variabel Service Information $t$ hitung (3.138) lebih besar dari $t$ table. Maka dapat dikatakan bahwa variabel Service Information berpengaruh secara signifikan terhadap Kepuasan Pengguna.

Untuk mengetahui pengaruh variabel Usability, Information Quality dan Service Interaction maka dapat dilihat berdasarkan uji F. Pada tabel diatas diperoleh nilai $F$ hitung (33.409) lebih besar dari $F$ tabel (3.12). Sehingga secara keseluruhan dinyatakan bahwa Usability, Information Quality dan Service Interaction berpengaruh signifikan terhadap Kepuasan Pengguna.

\section{Kesimpulan}

Hasil analisis memberikan kesimpulan bahwa di lingkungan STAIN Sultan Abdurrahman Kepri kualitas Usability memberikan pengaruh secara positif terhadap Kepuasan Pengguna Zoom Meeting dengan nilai koefisien regresi sebesar 0.086. Selanjutnya Information Quality juga berpengaruh secara positif terhadap Kepuasan Pengguna dengan nilai koefisien regresi 0.187. Demikian juga dengan kualitas Service Interaction yang memberikan pengaruh positif terhadap kepuasan pengguna Zoom Meeting dengan nilai koefisien regresi sebesar 0.439 .

Secara keseluruhan kualitas Usability, Information Quality dan Service Interaction berpengaruh positif terhadap kepuasan pengguna Zoom Meeting. Artinya, semakin tinggi nilai kualitas ketiga variabel tersebut maka semakin tinggi pula nilai Kepuasan Pengguna terhadap Zoom Meeting. Akan tetapi terdapat satu variabel yang memberikan pengaruh paling dominan terhadap Kepuasan Pengguna Zoom Meeting yaitu variabel Service Interaction yang ditunjukkan dengan nilai koefisien regresi paling tinggi yaitu sebesar 0.439 .

\section{Ucapan Terimakasih}

Penulis mengucapkan terima kasih kepada seluruh pihak yang telalh membantu dan memberikan dukungan hingga penelitian ini selesai tepat waktu. 


\section{Referensi}

Aryadita, Himawat., Widyastuti, D.A., \& Wardani, N. H. (2017). Analisis Kualitas Layanan Website ECommerce Terhadap Kepuasan Pengguna Menggunakan Metode Webqual 4.0. Studia Informatika: Jurnal Sistem Informasi, 10(1). 29-35.

Barnes, S. J., \& Vidgen, Richard. Measuring Web Site Quality Improvements: A Case Studi Of The Forum On Strategic Management Knowledge Exchange. Industrial Management \& Data System, 103(5). 297-309.

Fitroni, F. A., \& Marisa, Fitri. (2018). Analisis Kualitas Website Menggunakan Metode Webqual Pada Malang Dorm Hostel. Jurnal of Information Technology and Computer Science, 3(2), 61-68.

Manik, Agnes., Salamah, Irma., \& Susanti, Eka. (2017). Pengaruh Metode Webqual 4.0 Terhadap Kepuasan Pengguna Website Politeknik Negeri Sriwijaya. Jurnal Elektor Telekomunikasi Terapan, 477-484.

Marliana, R.R. (2020). Partial Least Squares-Structural Equation Meodeling Pada Hubungan Antara Tingkat Kepuasan Mahasiswa dan Kualitas Google Classroom Berdasarkan Metode Webqual 4.0. Jurnal Matematika, Statistika, \& Komputasi, 16(2). 174-186.

Sekaran. (2003). Metodologi Penelitian. Edisi Kelima. Jakarta. Ghalia Indonesia.

Sugiyono. (2013). Metode Penelitian Pendidikan Pendekatan Kuantitatif, Kualitatif, dan R\&DD. Bandung. Alfabeta

Syaifullah, \& Soemantri., D.O. (2016). Pengaruh Kualitas Website Menggunakan Metode Webqual 4.0 (Studi Kasus: CV. Zamrud Multimedia Network). Jurnal Rekayasa dan Manajemen Sistem Informasi, 2(1), 19-25 